\title{
STATUS GIZI BAYI 4 - 6 BULAN YANG MENDAPATKAN ASI EKSKLUSIF DAN ASI NON EKSKLUSIF DI PUSKESMAS KOLONGAN KECAMATAN KALAWAT KABUPATEN MINAHASA UTARA
}

\author{
Rudolf B. Purba' ${ }^{1}$, Fred A. Rumagit ${ }^{2}$, dan Rugayu Taher $^{3}$ \\ 1,2,3 Jurusan Gizi Politeknik Kesehatan Kemenkes Manado \\ Email korespondensi : rudolfboykepurba@gmail.com
}

\begin{abstract}
Exclusive breastfeeding is a baby receiving only direct breastfeeding from biological mother, breast milk or dairy milk until the baby is 6 months old. Non-exclusive breastfeeding is not only breastfed babies but also get other foods other than breastmilk like formula milk. North Sulawesi Province exclusive ASI coverage in 2014 amounted to $38.5 \%$ decreased 2015 only $26.3 \%$. The purpose of this research was to know the nutritional status of 4 - 6 months old baby who got exclusive breastfeeding and non exclusive breast milk. The type of research used is descriptive research. The study was conducted for 1 week from 30 May to 6 June 2017 at the Kolongan Community Health Center, Kalawat District, North Minahasa Regency The sample of the study was $4-6$ months old baby with total sample of 53 babies. Research respondents were infant mothers. The sampling method uses accidental sampling. Data obtained through interviews and direct measurement of nutritional status (BB / U) using baby scales (baby scale). The result of the research is the number of baby samples $4-6$ months as many as 53 babies. Exclusive breastfeeding of 16 infants. non exclusive breastfeeding of 37 babies, divided into infant formula, breast milk and formula mixture 17 infants. Nutritional status of infants $4-6$ months total of 53 babies, malnutrition less 4 babies (7.5\%), good nutrition 32 babies $(60,5 \%)$, and 17 more infants (32\%).
\end{abstract}

\section{Keywords: Nutrition Status, exclusive breastfeeding, non exclusive breast milk}

\section{PENDAHULUAN}

Kondisi ibu dan bayi di Indonesia saat ini masih memprihatinkan, masih banyak indikator gizi dan kesehatan ibu dan bayi yang perlu diperbaiki. Pendidikan dan pengetahuan masyarakat merupakan bagian penting yang harus ditingkatkan untuk memperbaiki kondisi ini. Sebagai contoh, peran ASI eksklusif terhadap kesehatan bayi dan ibu tidak diragukan, tetapi sampai saat ini prevalensi ASI eksklusif di Indonesia masih rendah. Berbagai penelitian menunjukkan bahwa pendidikan dan pengetahuan berkontribusi terhadap kondisi ini. Hampir semua ibu akan memprioritaskan kesehatan, pertumbuhan dan perkembangan bayinya bila mampu, namun keterbatasan pendidikan dan pengetahuan membuat mereka tidak dapat banyak berperan (Fikawati dkk, 2015).

Gizi ibu yang tidak baik pastinya akan berpengaruh buruk pada bayi. Sebab makanan yang di konsumsi oleh ibu yang sedang hamil merupakan nutrisi penting bagi pertumbuhan dan perkembangan janin. Semakin buruk nutrisi ibu semakin buruk pula nutrisi yang di terima janin. Sebaliknya semakin baik nutrisi ibu semakin baik pula nutrisi yang di terima janin (Indiarti dan Sukaca, 2015).

UNICEF (United Nation International Children Education Found) dan WHO (World Health Organization) merekomendasikan pemberian ASI eksklusif sampai bayi berumur 6 bulan, dan diberikan makanan padat dan semi padat sebagai makanan tambahan selain ASI. ASI dianjurkan pada beberapa bulan pertama 
kehidupan karena ASI tidak terkontaminasi dan mengandung banyak gizi yang diperlukan pada umur tersebut. Pengenalan dini makanan yang rendah energi dan gizi atau yang disiapkan dalam kondisi tidak higienis dapat menyebabkan anak mengalami kurang gizi dan terinfeksi organisme asing, sehingga mempunyai daya tahan tubuh yang rendah terhadap penyakit (Kementerian Kesehatan RI).

Berat badan bayi menurut umur merupakan salah satu indikator status gizi yang dapat dijadikan variabel dalam penelitian ilmiah yang dibedakan antara status gizi buruk, gizi kurang, gizi baik dan gizi lebih.Penilaian status gizi dapat di ketahui melalui dua cara yaitu secara langsung dan tidak langsung (Supariasa, dkk, 2001).

Menurut Survey Demografi (2012) makanan tambahan dan cairan diperkenalkan saat umur awal bayi, sekitar setengah anak berumur di bawah dua bulan menerima ASI eksklusif. Presentase ASI eksklusif menurun terus setelah dua bulan pertama. Lebih dari 7 di antara 10 anak umur $4-5$ bulan menerima makanan tambahan $(44 \%)$, air putih $(8 \%)$, susu dan cairan tambahan lainnya $(8 \%)$ sebagai tambahan dari ASI atau sepenuhnya yang sudah di sapih (13\%). Pada umur 4 - 5 bulan, lebih dari sepertiga anak di beri makanan bayi yang telah di fortifikasi.

Berdasarkan Riskesdas (2013), jenis makanan prelakteal yang paling banyak diberikan pada bayi adalah susu formula sebesar $79,8 \%$. Cakupan tertinggi susu formula di Provinsi Riau (95,5\%) dan Bali $(93,7 \%)$ sedangkan cakupan terendah susu formula di Provinsi Sulawesi Barat sebesar 40,2\%. Sementara di provinsi Sulawesi Utara cakupan susu formula sebanyak $88 \%$ dan masih tergolong cakupan cukup tinggi.

Target program tahun 2014 sebesar $80 \%$ secara nasional cakupan pemberian ASI eksklusif sebesar $52,3 \%$ belum mencapai target. Cakupan pemberian ASI eksklusif pada bayi 0 - 6 bulan di Provinsi Sulawesi Utara pada tahun 2014 sebesar $38,5 \%$ dan menurun pada tahun 2015 hanya sebesar $26,3 \%$ (Kementerian Kesehatan RI).

Berdasarkan hasil penelitian yang dilakukan sebelumnya di wilayah kerja Puskesmas Kema Kabupaten Minahasa Utara, terdapat 124 sampel pada bayi dengan umur 0 - 1 bulan sebanyak 98 bayi $(79,03 \%)$ yang mendapatkan ASI eksklusif, 1 - 2 bulan menurun menjadi 59,67\%, dan seiring bertambahnya usia bayi 2 - 4 bulan sebanyak 62 bayi (50\%) telah mendapatkan MP-ASI. Hal ini menunjukkan pemberian makanan tambahan ataupun pengganti ASI masih tinggi pada bayi di usia kurang dari 6 bulan (Paruntu, 2009).

Data Puskesmas Kolongan Kecamatan Kalawat Kabupaten Minahasa Utara pada tahun 2016 laporan bayi dengan cakupan ASI eksklusif pada usia 0 6 bulan pada bulan Agustus 2016 hingga Februari 2017 sebanyak 225 bayi dengan capaian ASI eksklusif hanya $32,1 \%$ dan tidak eksklusif sebesar $67.9 \%$. penelitian ini bertujuan untuk mengetahui perbedaan status gizi bayi yang mendapatkan ASI eksklusif dan ASI non eksklusif di wilayah kerja Puskesmas Kolongan Kecamatan Kalawat Kabupaten Minahasa Utara.

\section{METODE}

Jenis penelitian ini adalah penelitian descriptive dengan disain cross sectional study yaitu dalam pengukuran variable-variabelnya di lakukan hanya sekali dan pada waktu yang bersamaan. Penelitian dilaksanakan selama 1 minggu pada 30 Mei sampai dengan 6 Juni 2017 di Puskesmas Kolongan Kecamatan 
Kalawat Kabupaten Minahasa Utara. Variabel dalam penelitian ini adalah : Variabel bebas : pemberian ASI eksklusif dan ASI non eksklusif, dan variabel terikat : status gizi (BB/U).

Populasi dalam penelitian ini berjumlah 225 bayi dan menjadi sampel dalam penelitian ini adalah bayi berusia $4-6$ bulan yang datang berkunjung di Puskesmas dan Posyandu. Jumlah sampel yang di dapatkan sebanyak 53 bayi.

Responden pada pengambilan sampel adalah ibu bayi yang datang berkunjung di Puskesmas dan Posyandu yang berada dalam wilayah kerja Puskesmas Kolongan Kecamatan Kalawat Kabupaten Minahasa Utara. Metode pengambilan sampel dalam penelitian ini adalah menggunakan accidental sampling. Dimana pengambilan dilakukan secara aksidental untuk responden yang kebetulan ada atau bersedia.

Instrumen penelitian yang digunakan adalah kuesioner yang berisikan pengumpulan data yang berupa pertanyaan-pertanyaan tertulis (karakteristik responden dan sampel, serta pemberian ASI eksklusif dan ASI non eksklusif). Data antropometri menggunakan timbangan bayi (baby scale), alat tulis menulis, dan laptop. Pengolahan dan Analisis ; Data pemberian ASI eksklusif dan ASI non eksklusif menggunakan wawancara dengan menggunakan daftar pertanyaan, dan data yang dikumpulkan dari hasil wawancara dibuat dalam tabulasi data dan tabel frekuensi.

Analisa data diawali dengan pengambilan data tentang identitas sampel dan responden dengan menggunakan daftar pertanyaan. Kemudian dilakukan secara deskriptif dengan melihat presentasi data yang telah terkumpul dan di sajikan dalam bentuk tabel distribusi frekuensi dan narasi analisa data dilanjutkan dengan mambahas hasil penelitian menggunakan teori dan kepustakaan yang ada.

\section{HASIL DAN PEMBAHASAN}

\section{A. Karakteristik Responden}

a. Umur lbu Umur ibu yang memiliki bayi $4-6$ bulan sebagian besar ibu berumur $21-30$ thn sebanyak 31 ibu $(58,5 \%)$, lebih dari 30 thn sebanyak 16 ibu $(30,2 \%)$ dan kurang dari 20 thn sebanyak 6 ibu (11,3\%).

Tabel 1. Distribusi Frekuensi Umur Responden

\begin{tabular}{lcc}
\hline Umur ibu & $\mathrm{n}$ & $\%$ \\
\hline$<20$ thn & 6 & 11.3 \\
$21-30$ thn & 31 & 58.5 \\
$>30$ thn & 16 & 30.2 \\
\hline Total & 53 & 100 \\
\hline
\end{tabular}

Usia ibu sebagian besar berusia 21 - 30 tahun sebanyak 31 orang. 
b. Pendidikan Ibu

Pendidikan ibu sebagian besar SMA sederajat sebanyak 33 ibu $(62,3 \%)$, SMP sederajat sebanyak 14 ibu $(26,4 \%)$, dan SD sederajat sebanyak 6 ibu $(11,3 \%)$,

Tabel 2. Distribusi Frekuensi Pendidikan Ibu

\begin{tabular}{ccc}
\hline Pendidikan Ibu & $\mathrm{n}$ & $\%$ \\
\hline SD & 6 & 11.3 \\
SMP & 14 & 26.4 \\
SMA & 33 & 62.3 \\
\hline Total & 53 & 100 \\
\hline
\end{tabular}

Pendidikan merupakan proses menumbuh kembangkan seluruh kemampuan dan perilaku manusia melalui pengajaran. Tingkat pendidikan juga merupakan salah satu faktor yang mempengaruhi presepsi seseorang untuk lebih menerima ide-ide dan teknologi baru. Pendidikan ibu di samping modal utama dalam perekonomian rumah tangga juga berperan dalam penyusunan pola makan untuk keluarga, termasuk pemberian awal untuk buah hatinya (Notoatmodjo, 2010).

Pemberian makanan bayi berdasarkan tingkat pendidikan ibu/responden, yaitu pemberian ASI eksklusif dengan pendidikan SD sebanyak 6 orang, SMP 10 orang, dan SMA tidak ada. Pemberian susu formula dengan pendidikan SD tidak ada, SMP 4 orang, dan SMA 16 orang, pemberian campuran ASI dan susu formula dengan pendidikan SD 1 orang, SMP tidak ada, dan SMA sebanyak 16 orang, lebih jelas lihat tabel 5.

Tabel 3. Pendidikan Ibu dan Jenis Pemberian Makanan Bayi $4-6$ Bulan

\begin{tabular}{|c|c|c|c|c|c|c|c|c|}
\hline \multirow[t]{3}{*}{ Jenis Pemberian } & \multicolumn{6}{|c|}{ Pendidikan Ibu } & \multicolumn{2}{|c|}{ Total } \\
\hline & \multicolumn{2}{|c|}{ SD } & \multicolumn{2}{|c|}{ SMP } & \multicolumn{2}{|c|}{ SMA } & & \\
\hline & $\mathrm{n}$ & $\%$ & $\mathrm{n}$ & $\%$ & $\mathrm{n}$ & $\%$ & $\mathrm{n}$ & $\%$ \\
\hline ASI eksklusif & 6 & 85.7 & 10 & 71.4 & 0 & 0 & 16 & 30.2 \\
\hline Susu formula & 0 & 0 & 4 & 28.5 & 16 & 50 & 20 & 37.7 \\
\hline ASI + susu formula & 1 & 14.2 & 0 & 0 & 16 & 50 & 17 & 32 \\
\hline Jumlah & 7 & 99.9 & 14 & 99.9 & 32 & 100 & 53 & 100 \\
\hline
\end{tabular}

Pemberian ASI eksklusif terdapat pada pendidikan sekolah dasar (SD) dan sekolah menengah pertama (SMP). Sedangkan untuk pemberian ASI non eksklusif terdapat pada pendidikan sekolah menengah pertama (SMP) dan sekolah menengah atas (SMA).

Tingkat pendidikan orang tua/ibu memang cukup berpengaruh terhadap pemberian ASI eksklusif maupun ASI non eksklusif kepada bayi akan tetapi dari hasil penelitian diperoleh ternyata ibu dengan pendidikan sekolah menengah atas tetap memberikan ASI non eksklusif yaitu pengganti ASI seperti susu formula maupun campuran ASI dan susu formula kepada bayinya. 
c. Jumlah anak

Jumlah anak ibu sebagian besar berjumlah 1 anak sebanyak 24 ibu (45,3\%), 2 anak sebanyak (41,5\%) dan 3 anak sebanyak 7 ibu (13,2\%).

Sebagian besar ibu memiliki anak pertama sebanyak $24 \mathrm{ibu}$, anak ke dua 22 ibu dan anak ke tiga 7 ibu. Berdsarkan hasil ini, peneliti berasumsi bahwa sebagian besar ibu-ibu yang memiliki anak pertama memberikan ASI non eksklusif kepada bayi seperti susu formula maupun campuran susu formula, hal ini di pengaruhi oleh iklan susu formula dan pemahaman yang masih kurang mengenai ASI eksklusif.

d. Tempat Ibu Melahirkan

Tempat ibu melahirkan atau melakukan persalinan sebagian besar di Rumah Sakit sebanyak 27 ibu (50,9\%), Puskesmas sebanyak 24 ibu $(45,3 \%)$ dan melahirkan di Rumah sebanyak 2 ibu (3.8\%)..

Tabel 4. Distribusi Frekuensi Tempat Ibu Melahirkan

\begin{tabular}{ccc}
\hline Tempat ibu melahirkan & $\mathrm{n}$ & $\%$ \\
\hline Rumah sakit & 27 & 50.9 \\
Rumah & 2 & 3.8 \\
Puskesmas & 24 & 45.3 \\
\hline Total & 53 & 100 \\
\hline
\end{tabular}

Berdasarkan hasil penelitian tempat ibu melahirkan sebagian besar di rumah sakit dan di puskesmas. Responden yang melahirkan pada fasilitas kesehatan akan lebih mendukung dalam pemberian ASI eksklusif pada bayi, karena dibantu langsung oleh tenaga kesehatan. Adapun berdasarkan penelitian ditemukan bahwa masih ada responden melahirkan di rumah tetapi dibantu oleh tenaga kesehatan/bidan di daerah tersebut.

\section{B. Karakteristik Sampel}

Sebagian besar sampel bayi berumur $4-6$ bulan terdapat di wilayah kerja Puskesmas di Desa Watutumou II dan Kalawat masing-masing sebanyak 10 sampel.

a. Jenis Kelamin Bayi

Jenis kelamin sampel bayi yang diperoleh sebagian besar yaitu lakilaki sebanyak 27 bayi $(61,2 \%)$ dan perempuan sebanyak 26 bayi $(38.8 \%)$, dari total 53 bayi.

b. Umur Sampel

Umur sampel sebagian besar memiliki golongan umur 4 sampai 5 bulan masing-masing sebanyak 18 bayi (34\%), dan berumur 6 bulan sebanyak 17 bayi (32.1\%), dari total 53 bayi. 
Umur sangat memegang peran penting dalam penentuan status gizi, kesalahan penentuan akan menyebabkan interpretasi status gizi yang salah. Hasil penimbangan berat badan maupun tinggi badan yang akurat, menajadi tidak berarti bila tidak disertai dengan penentuan umur yang tepat. Ketentuannya adalah 1 tahun 12 bulan, 1 bulan 30 hari jadi perhitungan umur adalah dalam bulan penuh, artinya sisa umur dalam hari tidak diperhitungkan (Depkes, 2015).

c. Berat Badan Sampel Bayi $4-6$ Bulan

Berat badan sampel penelitian sebagian besar bayi berumur 4 sampai 6 bulan memiliki berat badan $6-6,9 \mathrm{~kg}$ dengan $7-7,9 \mathrm{~kg}$ masing-masing sebanyak 14 bayi (26,4\%), $5-5,9 \mathrm{~kg}$ sebanyak 9 bayi (17\%), $9-9.9 \mathrm{~kg}$ sebanyak 8 bayi (15.1\%) dan dengam berat badan $8-8,9 \mathrm{~kg}$ dengan $10-$ $10,9 \mathrm{~kg}$ masing-masing sebanyak 4 bayi $(7,5 \%)$. Berdasarkan hasil penelitian sebagian besar berat badan bayi $4-6$ bulan memiliki berat badan $6-6,9 \mathrm{~kg}$ dan $7-7,9 \mathrm{~kg}$ masing-masing sebanyak 14 bayi.

Pemantauan perkembangan status gizi bayi secara berskala setiap bulan, yaitu dengan cara menimbang berat badan dan mengukur panjang badannya. Idealnya, berat badan bayi berada di garis normal pada grafik pertumbuhan, artinya pertambahan berat badan seimbang dengan pertambahn tinggi badan dan usia (Choirunisa, 2009).

\section{Karakteristik Pemberian Makanan Bayi}

Jenis pemberian makanan bayi 4-6 bulan sebagian besar mendapatkan susu formula sebanyak 20 bayi $(37,7 \%)$, campuran ASI dan susu formula sebanyak 17 bayi (32\%) dan pemberian ASI eksklusif sebanyak 16 bayi $(30,2 \%)$.

Tabel 5 Distribusi Frekuensi Jenis Pemberian Makanan Bayi 4 - 6 Bulan

\begin{tabular}{ccc}
\hline Pemberian Makanan Bayi & $\mathrm{n}$ & $\%$ \\
\hline ASI & 16 & 30.2 \\
Susu Formula & 20 & 37.7 \\
ASI dan Susu Formula & 17 & 32 \\
\hline Total & 53 & 100 \\
\hline
\end{tabular}

Berdasarkan hasil penelitian di temukan bahwa untuk pemberian ASI eksklusif pada bayi $4-6$ bulan masih sangat kurang sementara untuk pemberian ASI non eksklusif cukup banyak.

Hasil ini sejalan dengan penelitian Fitri dkk (2014) yang dilaksanakan di Puskesmas Nanggalo, Kota Padang sebanyak 50 bayi didapatkan 15 bayi (30\%) mendapatkan ASI eksklusif dan selebihnya adalah ASI non eksklusif $(70 \%)$.

Keberhasilan pemberian ASI eksklusif dipengaruhi oleh pemberian ASI sejak dini terhadap bayi. Berdasarkan penelitian diketahui jarak waktu ibu memberikan ASI pada bayi setelah melahirkan sebagian besar yaitu 2 jam 
sebanyak 16 ibu (30,2\%), 15 menit sebanyak 15 ibu (28,3\%), 30 menit $(15,1 \%), 1$ jam sebanyak 6 ibu $(11,3 \%)$ dan 1 hari juga 2 hari masing-masing sebanyak 4 ibu $(7,5 \%)$.

Tabel 6. Distribusi Frekuensi Jarak Waktu Ibu Memberikan ASI Pada Bayi Setelah Melahirkan

\begin{tabular}{ccc}
\hline Jarak waktu pemberian & $\mathrm{n}$ & $\%$ \\
ASI setelah melahirkan & 15 & 28.3 \\
15 menit & 8 & 15.1 \\
30 menit & 6 & 11.3 \\
1 jam & 16 & 30.2 \\
2 jam & 4 & 7.5 \\
1 hari & 4 & 7.5 \\
2 hari & 53 & 100 \\
\hline Total & & \\
\hline
\end{tabular}

Inisiasi menyusui dini (IMD) sangat penting tidak hanya untuk bayi tetapi juga ibu, sekitar 22\% angka kematian bayi setelah lahir dapat di tekan dan penting dalam menjaga produktivitas ASI (Yuliarti 2010).

Berdsarkan penelitian yang dilakukan oleh Mumpuni dan Utami (2016) waktu inisiasi menyusu berpengaruh signifikan dalam kelangsungan pemberian ASI eksklusif untuk bayi $0-6$ bulan. Waktu inisiasi lebih dari satu jam pertama setelah kelahiran dengan waktu inisiasi dalam satu jam pertama adalah sebesar 1,661. Hal ini menunjukan waktu inisiasi menyusu lebih dari satu jam setelah kelahiran memiliki resiko 1,661 kali lebih besar dibandingkan dengan waktu inisiasi menyusu dalam satu jam pertama untuk memulai memberikan makanan lain selain ASI.

Terlaksananya pemberian ASI secara dini harus dimulai dari peran petugas kesehatan dalam melakukan proses pertolongan dalam persalinan karena pada saat itu peran petugas dalam pemberian ASI sejak dini dapat terlihat.

Berdsarakan hasil penelitian diketahui pemberian ASI sejak lahir hingga sekarang kepada bayi sebagian besar menjawab "ya" memberikan sebanyak 33 ibu (62,3\%) dan menjawab "tidak" memberikan sebanyak 20 ibu $(37,7 \%)$ dari total 53 ibu..

Tabel 7. Distribusi Frekuensi Pemberian ASI Sejak Lahir Hingga Sekarang

\begin{tabular}{ccc}
\hline $\begin{array}{c}\text { Pemberian ASI hingga } \\
\text { sekarang }\end{array}$ & $\mathrm{n}$ & $\%$ \\
\hline Ya & 33 & 62.3 \\
Tidak & 20 & 37.7 \\
\hline Total & 53 & 100 \\
\hline
\end{tabular}

Berdasarkan hasil penelitian dapat dilihat sebanyak 20 ibu tidak memberikan ASI pada bayinya hal ini di karenakan bayinya telah diberi susu formula sejak kelahiran pertama hingga sekarang. 
Usia bayi yang diberikan tambahan lain selain ASI kurang dari 6 bulan sebagian besar memberikan sejak lahir sebanyak 20 bayi (54\%), 1 bulan sebanyak 10 bayi (27\%), 2 bulan sebanyak 6 bayi $(16,2 \%)$ dan 3 bulan sebanyak 1 bayi $(2,7 \%)$ dari total 37 bayi.

Tabel 8. Distribusi Frekuensi Usia Bayi Diberikan Tambahan Lain Selain ASI Kurang dari 6 Bulan

\begin{tabular}{ccc}
\hline $\begin{array}{c}\text { Usia bayi mendapat tambahan } \\
\text { lain selain ASI }\end{array}$ & $\mathrm{n}$ & $\%$ \\
\hline Sejak lahir & 20 & 54 \\
1 bulan & 10 & 27 \\
2 bulan & 6 & 16.2 \\
3 bulan & 1 & 2.7 \\
\hline Total & 37 & 100 \\
\hline
\end{tabular}

Berdasarkan tabel dapat diketahui pemberian makanan lain kepada bayi $<6$ bulan sebagian besar memberikan sejak lahir 20 bayi, 1 bulan 10 bayi, 2 bulan 6 bayi dan 3 bulan 1 bayi.

Adapun penelitian yang dilakukan oleh Suherti (2011) menyebutkan bahwa, waktu pemberian makanan tambahan yang diberikan $<6$ bulan, anak akan lebih mudah mengalami gizi kurang dibandingkan anak yang diberikan makanan tambahan setelah 6 bulan. Hal ini disebabkan alat pencernaan bayi belum cukup kuat untuk mencerna makanan jika dipaksakan maka saluran pencernaannya mulai terinfeksi sehingga anak akan lebih mudah terserang penyakit yang diakibatkan dari daya tahan tubuh yang menurun.

Alasan ibu memberikan tambahan lain selain ASI kepada bayi kurang dari 6 bulan sebagian besar ASI tidak keluar sebanyak 12 ibu (32,4\%), operasi sebanyak 8 ibu (21,6\%), puting ibu tenggelam sebanyak 6 ibu (16,2\%), ASI terlambat keluar dan ibu bekerja masing-masing sebanyak 3 ibu $(8,1 \%)$ dari total $37 \mathrm{ibu}$.

Tabel 9. Distirbusi Alasan Ibu Memberikan Tambahan Lain Selain ASI Kepada Bayi Kurang dari 6 Bulan

\begin{tabular}{ccc}
\hline Alasan ibu & $\mathrm{n}$ & $\%$ \\
\hline ASI tidak keluar & 12 & 32.4 \\
ASI terlambat keluar & 3 & 8.1 \\
Bayi menolak menyusu & 5 & 13.5 \\
Puting tenggelam & 6 & 16.2 \\
Operasi & 8 & 21.6 \\
Ibu bekerja & 3 & 8.1 \\
\hline Total & 37 & 100 \\
\hline
\end{tabular}

Berdasarkan hasil penelitian dapat dlihat bahwa yang mempengaruhi pemberian ASI eksklusif pada bayi kurang dari 6 bulan dan menyebabkan sesorang tidak dapat menyusui bayi. Salah satunya ialah air susu tidak keluar. 
Penyebab air susu tidak keluar mulai dari stress mental sampai ke penyakit fisik, termasuk malnutrisi. Perilaku tidak menyusui bayi segera setelah lahir terutama dikondisikan oleh pemasaran susu formula, sekali terpengaruh dan terperangkap dengan sendirinya ASI tidak akan optimal atau tidak dapat keluar lagi. (Arisman, 2010).

Hasil penelitian yang dilakukan oleh Nilakesuma dkk (2015), jumlah bayi yang diberi ASI eksklusif lebih sedikit dari bayi yang tidak diberi ASI eksklusif. Pemberian ASI eksklusif dipengaruhi oleh banyak faktor, diantaranya sosial budaya, pengaruh promosi susu formula, dukungan petugas kesehatan, kesehatan ibu, kesehatan bayi, status pekerjaan ibu, tingkat pendidikan ibu dan pengetahuan serta sikap ibu.

Hal yang sama dikemukakan oleh Isnaini dan Apriyanti (2015), adanya hubungan pekerjaan ibu, pendidikan, dan akses informasi dengan pemberian susu formula. Alasan untuk tidak menyusui atau menghentikan menyusui lebih awal diantaranya karena promosi susu botol (PASI) yang berulang-ulang, dan banyak beredar dimedia elektornik maupun media cetak sehingga ibu berfikir bahwa susu formula sebanding bahkan melebihi manfaat ASI.

Distribusi apakah ASI ibu cukup hingga bayi berusia 6 bulan sebagian besar ibu menjawab tidak memberikan ASI sebanyak 20 ibu (37,7\%), kurang cukup sebannyak $17 \mathrm{ibu}(32 \%)$ dan sangat cukup sebanyak 16 ibu $(30,2 \%)$ dari total $53 \mathrm{ibu}$.

Tabel 10. Distribusi Frekuensi Apakah ASI Ibu Cukup Hingga Bayi Berusia 6 Bulan

\begin{tabular}{ccc}
\hline Kecukupan ASI ibu & $\mathrm{n}$ & $\%$ \\
\hline Tidak memberikan ASI & 20 & 37.7 \\
Kurang cukup & 17 & 32 \\
Sangat cukup & 16 & 30.2 \\
\hline Total & 53 & 100 \\
\hline
\end{tabular}

Berdasarkan hasil penelitian diketahui kecukupan ASI ibu sampai bayi berumur 6 bulan, sebanyak 20 ibu tidak memberikan ASI kepada bayi ibu, 17 ibu merasa kurang cukup dan 16 ibu merasa sangat cukup.

Kebutuhan nutrisi pada bayi berbeda dengan orang dewasa, baik dalam jumlah maupun proporsi karbohidrat, protein, lemak, vitamin, dan mineral. Kebutuhan nutrisi pada bayi akan terus mengalami perubahan seiring pertumbuhannya. Pada bayi, kebutuhan nutrisi sudah tercukupi melalui pemberian ASI dan atau susu formula. Untuk itu, tidak diperlukan penambahan makanan padat sebelum bayi menginjak usia 6 bulan (Riksani, 2015).

\section{Karakteristik Status Gizi Bayi 4 - 6 Bulan}

Status gizi bayi $4-6$ bulan di Puskesmas Kolongan sebagian besar memiliki status gizi baik sebanyak 32 bayi $(60,5 \%)$, gizi lebih sebanyak 17 bayi $(32 \%)$ dan gizi kurang sebanyak 4 bayi $(7,5 \%)$.

Status gizi untuk bayi $4-6$ bulan yang mendapatkan ASI eksklusif sebagian besar memiliki status gizi baik sebanyak 15 bayi $(93,8 \%)$ dan gizi kurang hanya 1 bayi $(6,2 \%)$ dari total 16 bayi.

Status gizi bayi $4-6$ bulan yang mendapatkan ASI Non Eksklusif yang terdiri dari campuran ASI dan susu formula sebagian besar memliki status 
gizi baik sebanyak 10 bayi $(58,8 \%)$, gizi lebih 5 bayi $(29,4 \%)$ dan status gizi kurang sebanyak 2 bayi $(11,8 \%)$. Sedangkan status gizi untuk bayi $4-6$ bulan yang mendapatkan susu formula sebagian besar memiliki status gizi lebih sebanyak 12 bayi (60\%), gizi baik sebanyak 7 bayi (35\%) dan gizi kurang 1 bayi $(5 \%)$ dari total 20 bayi.

Tabel 11. Distribusi Status Gizi Bayi $4-6$ Bulan

\begin{tabular}{ccccccccc}
\hline & \multicolumn{9}{c}{ Pemberian ASI } & & \\
\cline { 2 - 6 } Status gizi & ASI eksklusif & \multicolumn{3}{c}{ ASI Non Ekslusif } & \multirow{5}{*}{$\begin{array}{c}\text { Campuran } \\
\text { ASI \& susu } \\
\text { formula }\end{array}$} & $\begin{array}{c}\text { Susu } \\
\text { formula }\end{array}$ & & \\
\cline { 2 - 7 } & $\mathrm{n}$ & $\%$ & $\mathrm{n}$ & $\%$ & $\mathrm{n}$ & $\%$ & $\mathrm{n}$ & $\%$ \\
\hline Gizi kurang & 1 & 6.2 & 2 & 11.8 & 1 & 5 & 4 & 7.5 \\
Gizi baik & 15 & 93.8 & 10 & 58.8 & 7 & 35 & 32 & 60.5 \\
Gizi lebih & 0 & 0 & 5 & 29.4 & 12 & 60 & 17 & 32 \\
\hline \multicolumn{1}{c}{ Total } & 16 & 100 & 17 & 100 & 20 & 100 & 53 & 100 \\
\hline
\end{tabular}

Gizi seimbang untuk bayi 0-6 bulan cukup hanya dari ASI. ASI merupakan makanan yang terbaik untuk bayi karena dapat memenuhi semua zat gizi yang dibutuhkan bayi sampai usia 6 bulan, sesuai dengan perkembangan sistem pencernaan, murah dan bersih. Oleh karena itu setiap bayi harus memperoleh ASI eksklusif yang berarti sampai usia 6 bulan hanya diberi ASI saja (Depkes RI, 2015).

Pemberian makanan yang berkualitas dan kuantitasnya baik menunjang tumbuh kembang, sehingga bayi dapat tumbuh normal dan sehat/terbebas dari penyakit. Makanan yang diberikan kepada bayi dan anak akan digunakan untuk pertumbuhan badan, sehingga status gizi dan pertumbuhan dapat dipakai sebagai ukuran untuk memantau kecukupan gizi bayi dan anak (Hasdianah dkk, 2014).

Berdasarkan hasil penelitian ditemukan sebagian besar bayi dengan susu formula memliki status gizi lebih sebanyak 12 bayi. Pada umumnya bayi usia $4-6$ bulan yang mendapat susu formula mengalami kenaikan berat badan yang lebih cepat dibanding dengan bayi yang diberi ASI eksklusif. Kelebihan berat badan pada bayi yang mendapat susu formula karena kelebihan kandungan air dan komposisi lemak. Pada beberapa jenis susu formula sumber protein dan lemaknya berasal dari susu sapi (Khasanah, 2011).

Hasil penelitian ini sejalan dengan penelitian yang dilakukan oleh Setyaningsih \& Susilowati (2013), bayi dengan ASI eksklusif lebih banyak memiliki status gizi baik dibandingan bayi dengan PASI atau susu formula lebih banyak memiliki status gizi lebih. Bayi yang mengalami status gizi lebih dikarenakan oleh pemenuhan gizi yang tidak seimbang menurut keadaan bayi. Pemberian susu formula serta makanan pendamping ASI yang diberikan pada bayi kurang dari 6 bulan dengan intensitas yang tinggi dapat 
membahayakan dan berakibat kurang baik pada anak yang dampaknya adalah kerusakan pada usus bayi, karena pada umur demikian usus belum siap mencerna dengan baik sehingga pertumbuhan berat badan bayi terganggu antara lain adalah kenaikan berat badan yang terlalu cepat dan mengarah pada kegemukan atau obesitas.

\section{KESIMPULAN}

Status gizi bayi 4 - 6 bulan di Puskesmas Kolongan Kecamatan Kalawat Kabupaten Minahasa Utara yang gizi kurang 7,5\%, gizi baik $60,5 \%$, dan gizi lebih $32 \%$. Pemberian ASI eksklusif sebanyak 16 bayi, dengan status gizi baik sebanyak 15 bayi dan gizi kurang sebanyak 1 bayi. Pemberian ASI non eksklusif sebanyak 37 bayi, terbagi atas pemberian susu formula sebanyak 20 bayi dengan status gizi kurang 1 bayi, gizi baik 7 bayi dan gizi lebih sebanyak 12 bayi. Pemberian campuran ASI dan susu formula sebanyak 17 bayi dengan status gizi kurang 2 bayi, gizi baik 10 bayi dan gizi lebih 5 bayi. Disarankan perlu dilakukan konseling khususnya konseling menyusui kepada ibu-ibu yang mempunyai bayi balita dan ibu hamil agar dapat mempersiapkan diri untuk proses pemberian ASI selanjutnya setelah melahirkan.

\section{DAFTAR PUSTAKA}

Adriani, Merryana dan Bambang Wirjatmadi (2014) Gizi dan Kesehatan Balita. Kencana Prenadamedia Group, Edisi Pertama, Jakarta.

Almatsier, Sunita (2001). Prinsip Dasar IImu Gizi. Gramedia Pustaka Utama, Jakarta.

Arisman, MB (2010). Gizi Dalam Daur Kehidupan : Buku Ajar Ilmu Gizi, Ed 2. Buku Kedokteran EGC, Jakarta.

Choirunisa, Ana Maria (2009). Merawat Bayi dan Balita. Moncer Publisher, Cetakan Pertama, Yogyakarta.

Depkes, RI 2015. Pedoman Gizi Seimbang 2015. Dirjen Bina Gizi dan KIA. Jakarta.

Fikawati, Sandra., Ahmad Syafiq dan Khaula Karima (2015). Gizi Ibu dan Bayi, Rajawali Pers, edisi 1 cetakan 2, Jakarta.

Fitri, Dian Insana, Eva Chundrayetti, dan Rima Semiarti (2014). Hubungan Pemberian ASI Dengan Tumbuh Kembang Bayi Umur 6 Bulan di Puskesmas Nanggalo. Jurnal Kesehatan Andalas. 3 (2:136-140).

Indiarti, MT dan Bertiani Eka Sukaca (2015). Nutrisi Janin dan Bayi Sejak Dalam Kandungan. Parama IImu, cetakan 1, Yogyakarta.

Isnaini Nurul, dan Rika Apriyanti (2015). Faktor-faktor yang Berhubungan Dengan Pemberian Susu Formula Pada Bayi Umur 0 - 6 Bulan di BPS Agnes Way Kandis Bandar Lampung. Jurnal Kebidanan. 1 (1:1-4).

Jitowiyono, Sugeng. dan Weni, Kristiyanasari. (2011). Asuhan Kepertawatan Neonates dan Anak, Nuha Medika, cetakan 2, Yogyakarta.

Kemenkes, RI. 2014. Profil Kesehatan Indonesia, PDF di akses tanggal 04 November 2016.

Kemenkes, RI. 2015. Profil Kesehatan Indonesia, PDF di akses tanggal 04 November 2016.

Khasanah N, 2011. ASI Atau Susu Formula Ya ? Paduan Lengkap Seputar ASI Dan Susu Formula. Flashbook, Yogyakarta. 
Lawson Margaret, (2008). Makanan Sehat Untuk Bayi dan Balita. PT. Dian Rakyat, cetakan kedua, Jakarta.

Mumpuni, Retno Sari dan Efri Diah Utami (2016). Pengaruh Inisiasi Menyusui Dini dan Faktor Sosial Demografi Terhadap Ketahanan Pemberian ASI Eksklusif. E-Journal WIDYA Kesehatan dan Lingkungan. 1 (2: 116 - 121).

Montol, Ana B. (2009). Hubungan Pemberian Makanan Pendamping Air Susu Ibu Dengan Status Gizi Bayi Usia 6 - 12 Bulan Di Wilayah Kerja Puskesmas Sario. Jurnal Gizido. 1 (1: 30-37).

Nilakesuma, Aisyah Yusri Dianne dan Selfi Renita Rusjidi (2015) Hubungan Status Gizi dengan Pemberian ASI Ekslusif , Tingkat Pendidikan Ibu dan Status Ekonomi Keluarga di Wilayah Kerja Puskesmas Padang Pasir. Jurnal Kesehatan Andalas. 4 (1: 37 - 44).

Paruntu, Olga Lieke. (2009). Pengaruh Pemberian Asi Ekslusif Terhadap Pertumbuhan dan Status Gizi Bayi Pada Umur 0 - 4 Bulan Di Wilayah Kerja Puskesmas Kema Kecamatan Kema Kabupaten Minahasa Utara. Jurnal Gizido. 1 (1: 22-29).

Pujiani, Mega Rahmawati (2014). Analisis Faktor Pemberian ASI Eksklusif. Jurnal Edu Health. 4 (1: 53-58

Puskesmas Kolongan, 2016. Profil Kesehatan Puskesmas Kolongan Kecamatan Kalawat Kabupaten Minahasa Utara 2016.

Proverawati Atikah dan Siti Asfuah (2009). Buku Ajar Gizi Untuk Kebidanan. Nuha Medika, cetakan pertama Yogyakarta.

Rachmaniah, Nova (2014). Hubungan Tingkat Pengetahuan lbu Tentang ASI Dengan Tindakan ASI Eksklusif. WHO South - East Asia Journal of Public Health 1 (3:249-255)

Rahayu Setyaningsih dan Tri Susilowati (2013). Perbedaan Status Gizi Antara Bayi Yang Diberi ASI Dengan Bayi Yang Diberi PASI Pada Bayi Kurang Dari 6 Bulan Di Desa Kateguhan Kecamatan Sawit. Jurnal Kosala, JIK 1 $(2: 47-53)$

SDKI, 2012. Badan Kependudukan dan Keluarga Berencana Nasional, pdf di akses tanggal 20 Desember 2016.

Suherti, Tati (2011). Hubungan Pemberian Makanan Pendamping ASI Dengan Status Gizi Anak Usia 9-24 Bulan di Wilayah Kerja Puskesmas Pasirkaliki Kota Bandung. Jurnal Bhakti Kencana Medika, 1(1:45-49)

Sulistyoningsih Hariyani (2013) Gizi Untuk Kesehatan Ibu dan Anak, Graha IImu, edisi pertama Yogyakarta.

Supriasa, I Dewa Nyoman,. Bachyar, Bakri. \& Ibnu, Fajar (2001) Penilaian Status Gizi EGC, Jakarta.

Wulandari, Setyo Retno, dan Sri Handayani, (2011) Asuhan Kebidanan Ibu Masa Nifas, Gosyen Publishing, cetakan pertama, Yogyakarta 